\title{
SCIDice
}

\author{
International Journal of Dentistry and Oral Science (IJDOS) \\ ISSN: 2377-8075
}

\section{Evaluation Of Antioxidant Property Of Three Herbal Formulations - An In Vitro Study}

Research Article

Krisha Doshi ${ }^{1}$, Iffat Nasim $^{2 *}$

${ }^{1}$ Department of Conservative Dentistry and Endodontics, Saveetha Dental College and Hospitals, Saveetha Institute of Medical and Technical Sciences, Saveetha University, Chennai, India.

${ }^{2}$ Professor and Head of the Department, Department of Conservative Dentistry and Endodontics, Clinical Genetics Lab, Saveetha Dental College and Hospitals, Saveetha Institute of Medical and Technical Sciences, Saveetha University, Chennai - 600077, India.

\section{Abstract}

Background and Aim: Antioxidants have numerous applications in endodontics including irrigants, medicaments, postbleaching antioxidants, etc. Amla and Rosemary are well known antioxidants, but have never been combined. The aim of this study was to evaluate the antioxidant property of Amla, Rosemary and their combination as well as compare it with that of ascorbic acid.

Materials and Methods: Separate extracts of Amla and Rosemary were prepared by boiling $2 \mathrm{~g}$ each of powder in $100 \mathrm{ml}$ distilled water at $70^{\circ} \mathrm{C}$ for 30 mins. The combination extract was prepared by combining the two extracts. Antioxidant property was assessed using DPPH assay. The absorbances of both test and standard were analyzed at $517 \mathrm{~nm}$ after the incubation period. Percentage inhibition or percentage radical scavenging activity was assessed. One way ANOVA was used to assess the statistical significance between the groups.

Results: The \% inhibition of amla at 10, 20,30, 40 and $50 \mu \mathrm{l}$ concentrations was $75.81 \%, 73.32 \%, 90.26 \%, 75.85 \%$ and $68.41 \%$. That for rosemary was $56.59 \%, 58.46 \%, 89.48 \%, 81.92 \%$ and $77.45 \%$. While for the combination formulation, it was $88.56 \%, 84.12 \%, 96.02 \%, 88.8 \%$ and $97.56 \%$. Ascorbic acid showed the highest absorbance and antioxidant activity. The amla-rosemary combination showed results comparable to ascorbic acid.

Conclusion: The amla-rosemary combination formulation showed a synergistic effect and its antioxidant properties were comparable to that of ascorbic acid. The amla-rosemary extract has good potential to be used as a potent antioxidant in endodontics.

Keywords: Amla; Rosemary; Antioxidant; DPPH Assay; Endodontics.

\section{Introduction}

Oxygen is an element that is invaluable to all living organisms. Although it is an indispensable part of life, it can be both beneficial as well as poisonous to the health of a body. The free radical theory of oxygen toxicity proposed by Gerschman in 1954 states that the toxicity of oxygen is due to its partially reduced forms [1]. Free radicals are chemically active atoms that have a charge due to an excess or deficient number of electrons. They can be reactive oxygen species (ROS) or reactive nitrogen species (RNS) [2]. They are cytotoxic and are considered as the etiology for various diseases [3]. They may be beneficial in killing bacteria but may also damage the adjacent infected host tissues.

Free radicals are produced by various materials in dentistry including bleaching agents, composite resins, dental cements, ceramic restorations, metal restorations, dental implants and intracanal medicaments [4]. Hence the application of antioxidants in these fields is beneficial.

Among various antioxidants, $10 \%$ sodium ascorbate is the most widely used antioxidant in all investigations and laboratory studies [5]. Chemically, it is the sodium salt of ascorbic acid, and is also known as vitamin C. Sodium ascorbate has been proven to have strong free radical scavenging or antioxidant activity on oxidized

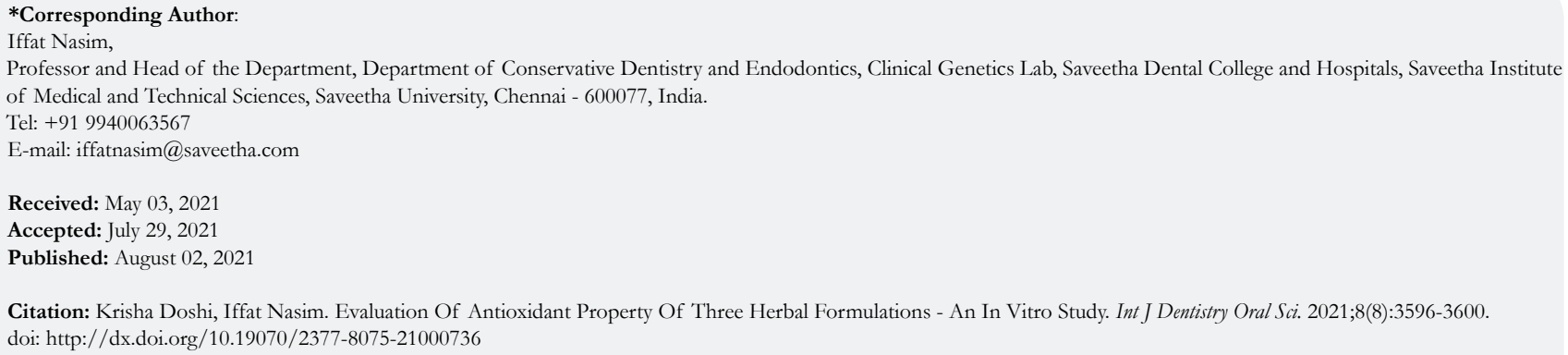

Copyright: Iffat Nasim ${ }^{\circ}$ 2021. This is an open-access article distributed under the terms of the Creative Commons Attribution License, which permits unrestricted use, distribution and reproduction in any medium, provided the original author and source are credited. 
enamel and dentin [6-8]. But, the major disadvantage of using it is that it is highly sensitive to ambient conditions such as heat, light, oxygen, humidity, $\mathrm{pH}$ and that loses its stability and effectiveness rapidly [9].

In the recent past, research is being focused towards use of natural herbal or plant extracts in order to develop a non-toxic, biocompatible, and effective material which can be applied safely to oxidized dental structures. Flavonoids, phenolic compounds or their derivatives in the composition of the natural plant extracts can prevent auto-oxidation via different mechanisms such as reducing or inhibiting oxygen formation, free radical scavenging, or metal ion chelating [10].

Amla (Emblicaofficinalis) is a well known antioxidant and has been used in medicine since ages. It is known to possess antioxidant, antimicrobial, anti-inflammatory properties. The presence of tannins, polyphenols and antioxidant acids are responsible for this property. In medicine, this herb has been used for the treatment of several conditions including diabetes, gastrointestinal disorders, high cholesterol, ophthalmic disorders, jaundice, diarrhoea, inflammations, etc $[11,12]$. In endodontics it has been used as a root canal irrigant, for smear layer removal, as an intracanal medicament, as a guttapercha disinfectant, etc [13-15]. Rosemary (Rosmarinusofficinalis) possesses antimicrobial, antifungal, antiinflammatory and antioxidant properties. In the field of endodontics, it has been used as an irrigant, intracanal medicament [16], post-bleaching antioxidant, etc [17].

Previously our team has a rich experience in working on various research projects across multiple disciplines [18-32] Now the growing trend in this area motivated us to pursue this project.

Since no previous study has combined these herbs, the aim of our study was to evaluate the antioxidant property of Amla, Rosemary, and their combination as well as compare it with that of ascorbic acid.

\section{Materials And Methods}

\section{Preparation of the extract}

Fresh amla and rosemary leaves were collected from a garden and were thoroughly double washed with running water. They were then dried under the shade for 5 days. The dried leaves were eventually crushed and powdered separately. $2 \mathrm{~g}$ each of Amla powder and Rosemary powder were added to $100 \mathrm{ml}$ of distilled water in two separate beakers and boiled at $70^{\circ} \mathrm{C}$ for $30 \mathrm{mins}$. This allows the phytochemicals present in the powder to get activated. The extract was collected from Whatman filter paper 1, and the filtrate was further boiled at $70^{\circ} \mathrm{C}$ for 15 mins. $2 \mathrm{ml}$ of each solution was measured with a micropipette and transferred to another test tube to make the Amla-Rosemary combination. The three solutions were stored for further use at low temperature.

\section{Evaluation of Antioxidant Property}

Hydrogen donating capacity or free radical scavenging by the nanoparticles was evaluated by the DPPH measure, which depends on the reduction of the methanoliccoloured radical type of the $\mathrm{DPPH}$ to the non-coloured solution. A measured quantity of
$0.2 \mathrm{mM}$ of DPPH was added to methanol solution, with the concentration of herbal solutions in a range of $10-50 \mu \mathrm{g} / \mathrm{ml}$. Ascorbic acid was used as the standard. The solution was vortexed and incubated for $30 \mathrm{~min}$ in dark conditions. The absorbances of both test and standard were analyzed at $517 \mathrm{~nm}$ after the incubation period. The antioxidant activity was calculated by the equation:

$\%$ Radical scavenging activity $=($ Absorbance of the control $-\mathrm{Ab}$ sorbance of the Test sample $) /($ Absorbance of the control) $\times 100$

\section{(Percentage Inhibition)}

\section{Statistical Analysis}

All the experimental results were performed in triplicate. The data was analysed using SPSS Software (Version 23.0). One way ANOVA was used to assess the statistical significance between the groups. A p-value $>0.05$ was considered statistically significant.

\section{Results And Discussion}

The absorbance values of the various samples at different concentrations is shown in Table 1.

The percentage radical scavenging activity of ascorbic acid at the different concentrations was considered as $100 \%$. In comparison, the $\%$ radical scavenging activity of amla at $10,20,30,40$ and $50 \mu \mathrm{l}$ concentrations was $75.81 \%, 73.32 \%, 90.26 \%, 75.85 \%$ and $68.41 \%$. That for rosemary was $56.59 \%, 58.46 \%, 89.48 \%$, $81.92 \%$ and $77.45 \%$. While for the combination formulation, it was $88.56 \%, 84.12 \%, 96.02 \%, 88.8 \%$ and $97.56 \%$. (Figure 3 ).

Ascorbic acid showed the highest absorbance and antioxidant activity. The antioxidant property of the combination formulation at $50 \mu \mathrm{l}$ conc was significantly higher than the individual extracts. The amla-rosemary combination showed results comparable to ascorbic acid.

Amla contains a wide range of tannins, alkaloids, and phenolic compounds, which make it highly antioxidant. In one previous study, extracts of a thousand different herbs were screened using sophisticated electron spin technology and Amla was one of only four chosen for both its superoxide radical scavenging activity [33]. Another study of three fruit extracts analysed their freeradical scavenging activity of hydroxyl, superoxide, nitric oxide, peroxynitrite, hypochlorous acid, etc. The authors concluded that Amla showed good efficacy in its antioxidant and radical scavenging abilities [34]. Yet another study of 30 different Thai medicinal plants traditionally used for diabetes found that five had strong antioxidant properties, of which Amla had the strongest antioxidant activity and the highest total polyphenol and tannin content [35].

For many years, it was thought that high amounts of ascorbic acid were a keystone for Amla's antioxidant power. Now it has been proven that amla also contains high amounts of gallic and ellagic acid other than ascorbic acid which are responsible for its antioxidant property [36-38]. It may be due to this reason that some authors believe that amla is a stronger antioxidant compared to ascorbic acid [39]. This is in contradiction to the results of our study which concluded that ascorbic acid had the highest antioxi- 
Table 1. Representing the absorbance values of the various formulations and ascorbic acid at different concentrations.

\begin{tabular}{|c|c|c|c|c|}
\hline \multirow{2}{*}{ CONC $(\mu \mathrm{l})$} & \multicolumn{4}{|c|}{ FORMULATION } \\
\cline { 2 - 5 } & Amla & Rosemary & Amla+Rosemary & Ascorbic Acid \\
\hline 10 & 0.682 & 0.524 & 0.82 & 0.926 \\
\hline 20 & 0.72 & 0.574 & 0.862 & 0.982 \\
\hline 30 & 0.926 & 0.918 & 0.986 & 1.026 \\
\hline 40 & 1.124 & 1.214 & 1.316 & 1.482 \\
\hline 50 & 1.286 & 1.456 & 1.834 & 1.88 \\
\hline
\end{tabular}

Figure 1. Demonstrating preparation of the herbal extracts.

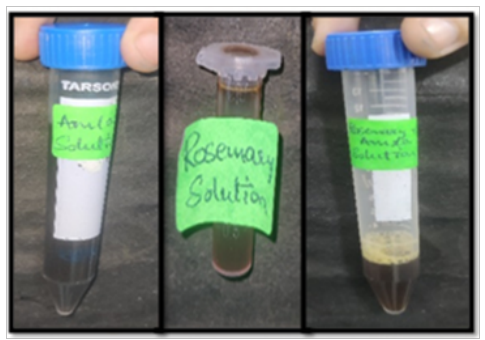

Figure 2. Showing the microtiter plate containing different concentrations of the herbal formulations as well as ascorbic acid.

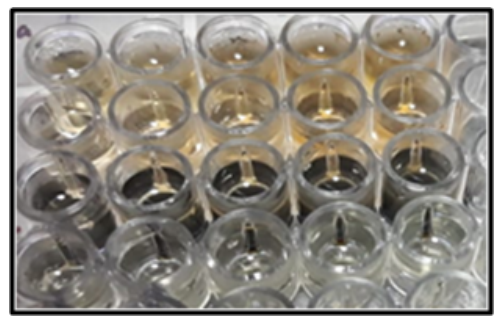

Figure 3. Representing a bar graph representing the radical scavenging activity or $\%$ inhibition of the different herbal formulations at various concentrations.

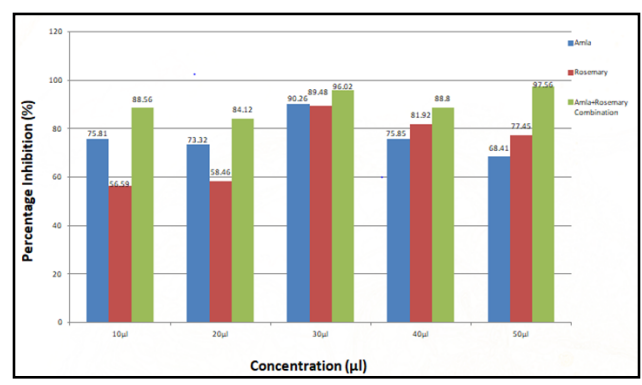

dant property.

Among the most effective antioxidant constituents of rosemary, the cyclic diterpenediphenols, carnosolic acid and carnosol, carnosic acid, epirosmanol, rosmanol, methylcarnosate and isorosmanol are the most important. The extract of rosemary also contains other caffeic acid derivatives. They react with metal ions, forming chelates; which react with peroxide free radicals stabilizing them. Höulihan et al. [40] and Wu et al. [41] determined that the antioxidant properties of rosemary are attributed to its richness in isoprenoidquinones, which act as chain terminators of free radicals, and as chelators of reactive oxygen species (ROS). In addition, Gordon [42] indicated that the phenolic compounds react with the lipid and hydroxyl radicals to turn them into stable products. According to Löliger [43], carnosic acid and carnosol act as potent scavengers of peroxyl radicals.

In our study, the combination formulation showed a synergistic effect and resulted in antioxidant property comparable to that of ascorbic acid. This may be due to the increased amount of flavonoids, phenolic compounds etc in the combination formulation. A previous study by Jain et al stated that the amla and green tea showed synergistic effect when combined with other herbs such as grapeseed, anar, cinnamon etc. [44].

DPPH assay is considered as a rapid, economic and widely used method for evaluation of antioxidant activity of products using different solvents including methanol, ethanol, water, alcohol, ethyl acetate, benzene. DPPH is a coloured and stable free radical, which gets reduced in the presence of an antioxidant compound to give yellow colour [45]. DPPH test is generally conducted for the evaluation of antioxidant activity of plant extracts and hence was the method of choice for our study.

Although amla and rosemary have shown good antioxidant properties, the future scope of our study is to extend its application as a post-bleaching antioxidant to replace sodium ascorbate as a natural and less toxic alternative. This involves performing many 
more in vitro studies to assess the shear bond strength of composite restorations, effect on bleaching, stability of the formulation, etc before clinical trials can be performed. The ultimate decision must be made only after long term randomized clinical trials. Our institution is passionate about high quality evidence based research and has excelled in various fields [22, 46-55].

\section{Conclusion}

Within the limitations of this study it can be concluded that the herbal formulations showed good antioxidant properties. The amla-rosemary combination formulation showed a synergistic effect and its antioxidant properties were comparable to that of ascorbic acid. The amla-rosemary extract has good potential to be used as a potent antioxidant in endodontics.

\section{Acknowledgement And Declarations}

The authors would like to acknowledge the institution and all the staff members of the Department of Conservative Dentistry and Endodontics for their support towards completion of this research. The authors deny any conflicts of interest associated with this paper.

\section{References}

[1]. Gerschman R. Oxygen poisoning and x-irradiation: a mechanism in common. Glutathione. 1954 Jan 1;119:623-626.

[2]. Shivanna V, Gupta S. Antioxidants; stressbusters in dentistry-a review. JDPR. 2013;1(2):9-19.

[3]. Chapple IL. Reactive oxygen species and antioxidants in inflammatory diseases. J ClinPeriodontol. 1997 May;24(5):287-96.

[4]. Patel S, Hans MK, Chander S, Ahluwalia AS. Antioxidants in Endodontics: A Strategic Review. J ClinDiagn Res. 2015 May;9(5):ZE12-5.Pubmed PMID: 26155593.

[5]. Nascimento GC, Guerreiro MY, Carvalho FF, Força AR, Loretto SC. Does sodium ascorbate improve bond strength after dental bleaching techniques?. RevistaOdontoCiência. 2015;30(4):205-10.

[6]. Feiz A, Mosleh H, Nazeri R. Evaluating the effect of antioxidant agents on shear bond strength of tooth-colored restorative materials after bleaching: A systematic review. J MechBehav Biomed Mater. 2017 Jul;71:156-164.Pubmed PMID: 28327437.

[7]. Lai SC, Tay FR, Cheung GS, Mak YF, Carvalho RM, Wei SH, et al. Reversal of compromised bonding in bleached enamel. J Dent Res. 2002 Jul;81(7):477-81

[8]. Türkün M, Kaya AD. Effect of $10 \%$ sodium ascorbate on the shear bond strength of composite resin to bleached bovine enamel. J Oral Rehabil. 2004 Dec;31(12):1184-91

[9]. LeBlanc JG, editor. Vitamin C: an Update on Current Uses and Functions. BoD-Books on Demand; 2019 May 10

[10]. Sonam KS, Guleria S. Synergistic antioxidant activity of natural products. Ann. Pharm. \& Pharm. 2017 Sep;2(16):1-6.

[11]. Khan KH. Roles of Emblicaofficinalis in medicine-A review. Bot Res Int. 2009;2(4):218-28.

[12]. Antony B, Merina B, Sheeba V, Mukkadan J. Effect of standardized Amla extract on atherosclerosis and dyslipidemia. Indian J. Pharm. Sci. 2006;68(4).

[13]. Dubey S. Comparative antimicrobial efficacy of herbal alternatives (Emblicaofficinalis, Psidiumguajava), MTAD, and 2.5\% sodium hypochlorite against Enterococcus faecalis: An in vitro study. J Oral BiolCraniofac Res. 2016 Jan-Apr;6(1):45-8.Pubmed PMID: 26937369.

[14]. Oncag O, Cogulu D, Uzel A, Sorkun K. Efficacy of propolis as an intracanal medicament against Enterococcus faecalis. Gen. Dent. 2006 Sep 1;54(5):319-22.

[15]. Ravishankar RK, Selvam D. EVALUATION OF DISINFECTION OF GUTTA PERCHA CONES USING HERBAL IRRIGANTS. ijsdr.org.

[16]. Silva S, Alves N, Silva P, Vieira T, Maciel P, Castellano LR, et al. Antibacterial Activity of Rosmarinusofficinalis, Zingiberofficinale, Citrus aurantiumbergamia, and Copaiferaofficinalis Alone and in Combination with Calcium Hydroxide against Enterococcus faecalis. Biomed Res Int. 2019 Dec 12;2019:8129439.Pubmed PMID: 31915705.
[17]. Gündoğdu S, Yılmaz NA. The Antioxidant Effect of Green Tea, Rosemary, and Their Combination on Resin Bond Strength to Bleached Tooth Structures. Meandros med. dental j. 2020;21(3):204-14.

[18]. Govindaraju L, Gurunathan D. Effectiveness of Chewable Tooth Brush in Children-A Prospective Clinical Study. J ClinDiagn Res. 2017 Mar;11(3):ZC31-ZC34.Pubmed PMID: 28511505.

[19]. Christabel A, Anantanarayanan P, Subash P, Soh CL, Ramanathan M, Muthusekhar MR, et al. Comparison of pterygomaxillarydysjunction with tuberosity separation in isolated Le Fort I osteotomies: a prospective, multi-centre, triple-blind, randomized controlled trial. Int J Oral Maxillofac Surg. 2016 Feb;45(2):180-5.Pubmed PMID: 26338075.

[20]. Soh CL, Narayanan V. Quality of life assessment in patients with dentofacial deformity undergoing orthognathic surgery--a systematic review. Int J Oral Maxillofac Surg. 2013 Aug;42(8):974-80.Pubmed PMID: 23702370.

[21]. Mehta M, Deeksha, Tewari D, Gupta G, Awasthi R, Singh H, et al. Oligonucleotide therapy: An emerging focus area for drug delivery in chronic inflammatory respiratory diseases. ChemBiol Interact. 2019 Aug 1;308:206215.Pubmed PMID: 31136735.

[22]. Ezhilarasan D, Apoorva VS, Ashok Vardhan N. Syzygiumcumini extract induced reactive oxygen species-mediated apoptosis in human oral squamous carcinoma cells. J Oral Pathol Med. 2019 Feb;48(2):115-121.Pubmed PMID: 30451321

[23]. Campeau PM, Kasperaviciute D, Lu JT, Burrage LC, Kim C, Hori M, et al. The genetic basis of DOORS syndrome: an exome-sequencing study. Lancet Neurol. 2014 Jan;13(1):44-58.Pubmed PMID: 24291220.

[24]. Sneha S. Knowledge and awareness regarding antibiotic prophylaxis for infective endocarditis among undergraduate dental students. Asian J Pharm Clin Res. 2016 Oct 1:154-9.

[25]. Christabel SL, Linda Christabel S. Prevalence of type of frenal attachment and morphology of frenum in children, Chennai, Tamil Nadu. World J Dent. 2015 Oct;6(4):203-7.

[26]. Kumar S, Rahman R. Knowledge, awareness, and practices regarding biomedical waste management among undergraduate dental students. Asian J Pharm Clin Res. 2017;10(8):341.

[27]. Sridharan G, Ramani P, Patankar S. Serum metabolomics in oral leukoplakia and oral squamous cell carcinoma. J Cancer Res Ther. 2017 Jul 1;13(3):556561.

[28]. Ramesh A, Varghese SS, Doraiswamy JN, Malaiappan S. Herbs as an antioxidant arsenal for periodontal diseases. J IntercultEthnopharmacol. 2016 Jan 27;5(1):92-6.Pubmed PMID: 27069730.

[29]. Thamaraiselvan M, Elavarasu S, Thangakumaran S, Gadagi JS, Arthie T. Comparative clinical evaluation of coronally advanced flap with or without platelet rich fibrin membrane in the treatment of isolated gingival recession. J Indian SocPeriodontol. 2015 Jan;19(1):66-71.

[30]. Thangaraj SV, Shyamsundar V, Krishnamurthy A, Ramani P, Ganesan K, Muthuswami M, et al. Molecular Portrait of Oral Tongue Squamous Cell Carcinoma Shown by Integrative Meta-Analysis of Expression Profiles with Validations. PLoS One. 2016 Jun 9;11(6):e0156582.Pubmed PMID: 27280700 .

[31]. Ponnulakshmi R, Shyamaladevi B, Vijayalakshmi P, Selvaraj J. In silico and in vivo analysis to identify the antidiabetic activity of beta sitosterol in adipose tissue of high fat diet and sucrose induced type- 2 diabetic experimental rats. ToxicolMech Methods. 2019 May;29(4):276-290.Pubmed PMID: 30461321.

[32]. Ramakrishnan M, Shukri M. Fluoride, Fluoridated Toothpaste Efficacy And Its Safety In Children-Review. Int J Pharm Res. 2018 Oct 1;10(04):109-14.

[33]. Niwano Y, Saito K, Yoshizaki F, Kohno M, Ozawa T. Extensive screening for herbal extracts with potent antioxidant properties. J ClinBiochem Nutr.2011; 48:78-84

[34]. Hazra B, Sarkar R, Biswas S, Mandal N. Comparative study of the antioxidant and reactive oxygen species scavenging properties in the extracts of the fruits of Terminaliachebula, Terminaliabelerica and Emblicaofficinalis. BMC Complement Altern Med. 2010 May 13;10:20.Pubmed PMID: 20462461.

[35]. Kusirisin W, Srichairatanakool S, Lerttrakarnnon P, Lailerd N, Suttajit M, Jaikang C, et al. Antioxidative activity, polyphenolic content and anti-glycation effect of some Thai medicinal plants traditionally used in diabetic patients. Med Chem. 2009 Mar;5(2):139-47.Pubmed PMID: 19275712.

[36]. Nampoothiri SV, Prathapan A, Cherian OL, Raghu KG, Venugopalan VV, Sundaresan A. In vitro antioxidant and inhibitory potential of Terminaliabellerica and Emblicaofficinalis fruits against LDL oxidation and key enzymes linked to type 2 diabetes. Food ChemToxicol. 2011 Jan;49(1):12531.Pubmed PMID: 20951180.

[37]. Poltanov EA, Shikov AN, Dorman HJ, Pozharitskaya ON, Makarov VG, Tikhonov VP, et al. Chemical and antioxidant evaluation of Indian gooseberry (EmblicaofficinalisGaertn., syn. Phyllanthusemblica L.) supplements. Phytother Res. 2009 Sep;23(9):1309-15.Pubmed PMID: 19172666.

[38]. Kumaran A, Karunakaran RJ. Nitric oxide radical scavenging active 
components from Phyllanthusemblica L. Plant Foods Hum Nutr. 2006 Mar;61(1):1-5.Pubmed PMID: 16688481

[39]. Majeed M, Bhat B, Jadhav AN, Srivastava JS, Nagabhushanam K. Ascorbic acid and tannins from Emblicaofficinalis Gaertn. Fruits--a revisit. J Agric Food Chem. 2009 Jan 14;57(1):220-5.Pubmed PMID: 19063633.

[40]. Houlihan CM, Ho CT, Chang SS. The structure of rosmariquinone-A new antioxidant isolated fromRosmarinusofficinalis L. J Am Oil Chem Soc. 1985 Jan;62(1):96-8.

[41]. Wu JW, Lee MH, Ho CT, Chang SS. Elucidation of the chemical structures of natural antioxidants isolated from rosemary. J Am Oil Chem Soc. 1982 Aug;59(8):339-45.

[42]. Gordon MH. The mechanism of antioxidant action in vitro. InFood antioxidants. 1990 (pp. 1-18). Springer, Dordrecht.

[43]. Aruoma OI, Halliwell B. Free radicals and food additives.1991.

[44]. Jain DP, Pancholi SS, Patel R. Synergistic antioxidant activity of green tea with some herbs. J Adv Pharm Technol Res. 2011 Jul;2(3):177-183.

[45]. Brand-Williams W, Cuvelier ME, Berset CL. Use of a free radical method to evaluate antioxidant activity. LWT - Food Sci. Technol. 1995 Jan $1 ; 28(1): 25-30$.

[46]. VijayashreePriyadharsini J. In silico validation of the non-antibiotic drugs acetaminophen and ibuprofen as antibacterial agents against red complex pathogens. J Periodontol. 2019 Dec;90(12):1441-1448.Pubmed PMID: 31257588 .

[47]. Pc J, Marimuthu T, Devadoss P, Kumar SM. Prevalence and measurement of anterior loop of the mandibular canal using CBCT: A cross sectional study. Clin. Implant Dent. Relat. Res. 2018 Apr 6;20(4):531-4.

[48]. Ramesh A, Varghese S, Jayakumar ND, Malaiappan S. Comparative estimation of sulfiredoxin levels between chronic periodontitis and healthy patients
- A case-control study. J Periodontol. 2018 Oct;89(10):1241-1248.Pubmed PMID: 30044495.

[49]. Ramadurai N, Gurunathan D, Samuel AV, Subramanian E, Rodrigues SJ. Effectiveness of $2 \%$ Articaine as an anesthetic agent in children: randomized controlled trial. Clin Oral Investig. 2019 Sep;23(9):3543-50.

[50]. Sridharan G, Ramani P, Patankar S, Vijayaraghavan R. Evaluation of salivary metabolomics in oral leukoplakia and oral squamous cell carcinoma. J Oral Pathol Med. 2019 Apr;48(4):299-306.

[51]. Mathew MG, Samuel SR, Soni AJ, Roopa KB. Evaluation of adhesion of Streptococcus mutans, plaque accumulation on zirconia and stainless steel crowns, and surrounding gingival inflammation in primary molars: randomized controlled trial. Clin Oral Investig. 2020 Sep;24(9):1-6.Pubmed PMID: 31955271

[52]. Samuel SR. Can 5-year-olds sensibly self-report the impact of developmental enamel defects on their quality of life? Int J Paediatr Dent. 2021 Mar;31(2):285-286.Pubmed PMID: 32416620.

[53]. R H, Ramani P, Ramanathan A, R JM, S G, Ramasubramanian A, et al. CYP2 C9 polymorphism among patients with oral squamous cell carcinoma and its role in altering the metabolism of benzo[a]pyrene. Oral Surg Oral Med Oral Pathol Oral Radiol. 2020 Sep;130(3):306-312.Pubmed PMID: 32773350 .

[54]. Chandrasekar R, Chandrasekhar S, Sundari KKS, Ravi P. Development and validation of a formula for objective assessment of cervical vertebral bone age. ProgOrthod. 2020 Oct 12;21(1):38.Pubmed PMID: 33043408.

[55]. Priyadharsini JV, Girija AS, Paramasivam A. In silico analysis of virulence genes in an emerging dental pathogen A. baumannii and related species. Arch Oral Biol. 2018 Oct 1;94:93-8. 